\title{
Denizli Büyükşehir Belediyesinin 2016-2017 Yılı Sosyal Sorumluluk Projeleri Üzerine Bir Araştırma ${ }^{1}$
}

\author{
A Research On Social Responsibility Projects Of Denizli Metropolitan Municipality \\ In 2016-2017
}

\author{
Emine Vasfiye KORKMAZ* \\ Adnan CELIK ${ }^{* *}$ \\ Yaşar KORKMAZ*** \\ Emel $E F E^{* * * *}$
}

\section{$\ddot{O} Z$}

Sosyal sorumluluk kavramı kurum imajı açısından son derece güncel ve önemli bir kavram, aynı zamanda örgütler ve müşteriler arasında önemli bir iletişim aracıdır. Kurumsal sosyal sorumluluk kavramı, literatüre yeni girmiş olmasina karşın konuya duyulan ilgi önemlidir. Bu çalışma; sosyal sorumluluk, yerel yönetimler ve yerel yönetimlerde sosyal sorumluluk bağlamında sosyal belediyecilik kavramları ele alınmıştır. Çalışmada Denizli belediyesi hakkında bilgi verilip, Denizli Belediyesi'nin 2016 ve 2017 yllar arasinda yürütülen ve tamamlanan projeleri ve faaliyetleri sosyal sorumluluk bakış açısı altında incelenmiştir. Çalışmanın amacı belediyelerin yürüttü̈̆̈̈ sosyal sorumluluk faaliyetlerine yönelik araştırmalara farklı bakış açısı geliştirmeyi ve kurumsal sosyal sorumluluk konusunda akademik yazına fayda sağlayacak bilgiler sunmayı amaçlamıştır.

\author{
ANAHTAR KELIMELER \\ Yerel Yönetimler, Sosyal Sorumluluk, Denizli Belediyesi
}

\begin{abstract}
The concept social responsibility is an extremely current and important corporate image in terms of concept, but also an important communications tool between organizations and customers. Although the concept of corporate social responsibility has recently entered the literature, interest in the issue is important. Local authorities, that are formed in order to satisfy the needs of residents, are public institutions that have the responsibilities to society. In this work, social responsibility, local governance and the concept of social responsibility at local government was addressed in the context of social municipality. Later, brief information about Denizli municipality was given and completed and ongoing projects years between 2016 and 2017 was evaluated within the perspective of social responsibility. The aim of the study was to develop a different perspective on the researches about the social responsibility activities carried out by the municipalities and to provide information to the academic literature on corporate social responsibility.
\end{abstract}

\section{KEYWORDS}

Local Government, Social Responsibility, Denizli Municipality

\begin{tabular}{|c|l|c|}
\hline \multicolumn{2}{|c|}{$\begin{array}{l}\text { Makale Geliş Tarihi / Submission Date } \\
21.09 .2018\end{array}$} & \multicolumn{1}{c|}{$\begin{array}{c}\text { Makale Kabul Tarihi / Date of Acceptance } \\
\text { 08.08.2019 }\end{array}$} \\
\hline \multirow{3}{*}{ Atıf } & $\begin{array}{l}\text { Korkmaz, E.V., Çelik, A., Korkmaz, Y. Ve Efe, E. (2019). Denizli Büyükşehir Belediyesinin 2016-2017 Y1lı Sosyal } \\
\text { Sorumluluk Projeleri Üzerine Bir Araştırma. Selçuk Üniversitesi Sosyal Bilimler Meslek Yüksekokulu Dergisi, 22 (2), } \\
\text { 345-354. }\end{array}$ \\
\hline
\end{tabular}

\footnotetext{
${ }^{1}$ Bu çalışmanın özeti 27-29 Nisan 2018 1. Uluslararası Girişimcilik ve Sosyal Bilimler Kongresi-Kıbrıs'ta sunulmuştur

* Öğr. Gör. Dr., İskenderun Teknik Üniversitesi, Dörtyol MYO, eminekorkmaz@iste.edu.tr ORCİD: 0000-0001-7202-6849

** Prof. Dr., Selçuk Üniversitesi, İktisadi İdari Bilimler Fakültesi, adnancelik@selcuk.edu.tr ORCID: 0000-0002-8538-9937

*** Öğr. Gör., İskenderun Teknik Üniversitesi, Dörtyol MYO, yasar.korkmaz@iste.edu.tr ORCID: 0000-0002-2901-4348

**** Mezun Lisans Öğrencisi, Selçuk Üniversitesi Beyşehir Ali Akkanat İşletme Fakültesi, emelefe_20@hotmail.com ORCIDD: 0000-0002-8289-5332
} 


\section{GIRIŞ}

Kurumsal sosyal sorumluluk projeleri günümüzde işletmelerin toplumsal itibarı açısından yatırım yaptıkları önemli faaliyetlerden biridir. Bu durum sadece özel sektörde yer alan kurumlar için değil aynı zamanda kamu kurumları için de hayati öneme sahiptir.

Birçok kamu kurumu gibi belediyeler de hazırladıkları sosyal sorumluluk projeleri ile toplumun refahına ve huzuruna katkı sağlamayı, çalışanlarına daha motive olacakları iş imkânları sunmayı hedeflemektedir. Bu sosyal sorumluluk projeleri sadece büyük şehir belediyeleri değil küçük ilçe belediyeleri tarafindan bile topluma daha iyi hizmet sunmak, toplumdaki eşitsizleri azaltmak adına sürekli uygulanır hale gelmiştir. Bu araştırma Selçuk Üniversitesi Beyşehir Ali Akkanat İşletme Fakültesi, İşletme bölümü 2016-2017 lisans bitirme tezi kapsamında Denizli belediyesinin 2016-2017 yıllarında halka sunmuş olduğu sosyal sorumluluk projelerinin değerlendirilmesine yönelik sonuçların sunulması adına hazırlanmıştır.

\section{LITERATÜR ÖZETİ}

\subsection{Sosyal Sorumluluk}

Her organizmanın hedefi etrafına uyan bir yapıda hayatını sürdürmesi ve bu durumu sürekli hale getirmedir. Bahsedilen bu organizma, bir kamu kuruluşu, bir dernek, din kurumu, bir işletme gibi toplumsal ve ekonomik kuruluş olabilir (Efil, 2013:308). Geçmişte çok önemsenmese de günümüzde gerek özel gerek kamu kuruluşlarının birincil konuları arasına sosyal sorumluluk kavramı dâhil olmuştur. İşletmeler açısından, kar ederken topluma ve paydaşlarına karşı duyarlı, çalışanlarının ve toplumun huzurunu ve refahını düşünen, topluma fayda yaratan projeler içerisinde yer alarak itibar kazanmak hergeçen gün daha da önemli hale gelmiştir. Bu doğrultuda kurumların itibarı açısından sosyal sorumluluk araştırılması gereken önemli bir konu haline gelmiştir.

Sosyal sorumluluk, işletmelerin müşteri ve çalışanları için sosyal, ekonomik ve kültürel açıdan, eğitim durumları açısından, etik ve ahlaki durumları açısından uygun uygulamaların geliştirilmesini öngörür. Çevreye zarar vermeden insanların ihtiyaçlarını karşılama konusunda duyarlı olmayı ve bu sosyal sorumluluk faaliyetlerini herhangi bir zorlama ile değil tamamen gönüllülük esası ile gerçekleştirmesini ifade etmektedir (Gülcan, 2019: 5).

Sosyal sorumluluk kavramı ile ilgili olarak tarihi sürece bakıldığında, üç aşamada önemli gelişmeler olmuştur. Bu aşamalar; işletmeler kurulmadan önceki dönem, sanayi devrimi öncesi dönem ve sanayi devrimi sonrası olarak üç aşamada bahsedilebilir. Sosyal sorumluluğun tarih içindeki değişim ve gelişim aşamaları medeniyetler ve dinlerin ortaya çıkışına kadar dayanmaktadır (Aktaran: Sarıca ve Yüksel, 2012:50).

Sosyal sorumluluk; "işletmenin ekonomik faaliyetlerini, çalışanlar, hissedarlar, tüketiciler ve toplumdaki bireylerin hiçbirine zarar vermeden, sahip olduğu kıt kaynakları en iyi biçimde kullanarak toplumun istek ve arzularına uygun üretimde bulunması" olarak açıklanabilir (Şimşek, Çelik ve Akgemci, 2016:363).

Sosyal Sorumluluğun avantajları ve dezavantajları (Aktaran: Harman, 2014:14) şu şekilde sıralanabilir;

Tablo 1: Sosyal Sorumluluğun Avantajları Ve Dezavantajları

\begin{tabular}{|l|l|}
\hline \multicolumn{1}{|c|}{ Avantajları } & \multicolumn{1}{|c|}{ Dezavantajları } \\
\hline 1. Sosyal sorumluluğa önem veren şirketlerin \\
marka değerleri ve dolayısıyla piyasa değerleri \\
artıyor. & $\begin{array}{l}\text { 1. Sosyal faaliyetlerin ürün maliyetlerine } \\
\text { yansitılmasıyla fiyatlar artar, bu da pazar kaybına } \\
\text { neden olabilir. }\end{array}$ \\
$\begin{array}{l}\text { 2. Daha nitelikli personeli cezbetme, motive etme } \\
\text { ve tutma imkânı doğuyor. }\end{array}$ & $\begin{array}{l}\text { 2. Sosyal faaliyetler için yeni insan kaynağına } \\
\text { ihtiyaç duyulabilir. }\end{array}$ \\
3. Kurumsal öğrenme ve yaratıcılık potansiyeli & $\begin{array}{l}\text { 3. İşletme sahip, ortak veya yöneticilerinin sosyal } \\
\text { artıyor. }\end{array}$ \\
4. Özenulara fazla duyarlı davranmaları, örgütsel \\
ulaşmaçlardan uzaklaşılmasına neden olabilir. \\
artıyor, gerekse borçlanma malarda hassas yatırımcılara \\
5. Yeni pazarlara girmekte ve müşteri sadakati \\
sağlamada önemli avantalar elde ediliyor
\end{tabular}




\subsection{Kurumsal Sosyal Sorumluluk}

Kurumsal sosyal sorumluluk kavramı her geçen gün, işletmelerin tüm paydaşları açısından sorumluluklarını yerine getirmesi, almış olduğu karar ve uyguladığı faaliyetlerde bu paydaşların da çıkarlarını gözetmesi olarak ifade edilebilir. Bu açıdan işletmeler, müşteri, toplum, tüketiciler ve çalışanlar gibi işletmeden çıkar elde eden tüm kişi ve grupları etkileyecek sosyal sorumluluk faaliyetlerini en iyi şekilde sürdürmelidir. Kurumsal sosyal sorumluluk faaliyetlerinin verimli bir biçimde sürdürülmesi için tüm paydaşların bu faaliyetleri desteklemesi ve hedeflerine varmasını sağlaması gerekmektedir (Tekin, 2018: 32).

Şirketlerin sosyal sorumluluğu kapsamında, öncelikle; "iş yaşamı, tüketiciler ve ekolojik çevreye karşı olan sosyal sorumluluklar" olmak üzere üç temel boyut üzerinde durulabilir. Özelde ise, bu kapsam; "ülkeden ülkeye, toplumdan topluma, bölgeden bölgeye, şirketten şirkete" farklılık gösterebilir. Bu bağlamda "1tüketicinin korunması, 2-istihdam olanakları ve çalışma koşullarının iyileştirilmesi, 3-sermayedar ve hissedarlara karşı yükümlülükler, 4-iş ahlakı, 5-ekolojik yapıya duyarlılık ve çevre kirliliğinin önlenmesi, 6toplum ve bütün insanlık" gibi ölçütler genel kabul görmektedir. Sosyal sorumluluk kapsamında siralanan söz konusu ölçütlerin ayrı ayrı tanımlanmasında yarar vardır (Çelik, 2007:66).

İşletmeler kurumsal sosyal sorumluluğu tüm fonksiyonlarına adapte etmiştir. Özellikle hassa bir konu olan muhasebe uygulamalarının yürütülmesinde ve mali tabloların düzenlenmesi ve sunulmasında, belli kişi ve grupların değil toplumun tüm kesiminin çıkarlarının gözetilmesi temel muhasebe kavramları içerisinde sosyal sorumluluk kavramının ilk sırada olmasını sağlamıştır (Şimşek ve Çelik, 2015:264).

Kurumsal Sosyal sorumluluğu Bakan ve Doğan (2011:215) bir piramidin 4 basamağı olarak aktarmıştır. Bu basamaklardan ilki ekonomik sorumluluklar, ikincisi etik sorumluluklar, üçüncüsü yasal sorumluluklar ve son olarak hayırsever odaklı sorumluluklardır. Ekonomik sorumluluklar kar elde etme odaklı, yasal sorumluluklar kanuni ve yasalara uygun hareket etme odaklı, etik sorumluluklar sosyal sorumluluğun çekirdeğini oluştururken, hak ve adalete uygun sorumluluklar odaklı ve hayırsever odaklı sorumluluklar gönüllülük esasına dayanan sorumluluklardır.

\subsection{Yerel Yönetimlerde Sosyal Sorumluluk ve Denizli Belediyesine Ait Bazı Sosyal Sorumluluk Projeleri}

Kurumların sosyal sorumlulukları, modern yönetim anlayışında üzerinde durulan ve tartışılan bir konu haline ve böylece tüm kurumlara topluma hizmet amacı ile herhangi bir çıkar gözetmeksizin ve bir ayrım yapmaksızın hizmet götürme zorunluluğu ortaya çıkmıştır (Akman, 2009:28).

Belediyelerde halka sunulan hizmetlerin hizmete bağlı özellikleri eksiksiz içinde barındırması, etkin, verimli ve zamanında üretilmesi yetmez, bu hizmetin aynı zamanda vatandaşı memnun edecek biçimde vatandaşlara sunulması önemli bir durumdur. Yapılacak işin özelliğine göre de belediyenin bünyesinde yer alan bölümlere bu konuda sorumluluklar düşmektedir (Sarıca ve Yüksel, 2012:54).

Belediyeler şehirlerin gelişmesi ve o şehirde yaşayan halkın ortak ihtiyaçlarının karşılanması konusunda stratejik öneme sahip kurumlardır. Bu nedenle belediyenin vizyonu , halkının belediyeden beklediği hizmetleri kaliteli, verimli, etkin biçimde gerçekleştirmek ve bu çalışmalarıyla da diğer kurum ve kuruluşlara örnek olmak dır. Belediyeler belde ve belde halkına hizmet için kurulmuş kamu tüzel kişilikleri oldukları için beldeye ve belde halkına yönelik hizmetler sunmaktadırlar. Dolayısıyla, belediyeler için kalite, belde ve belde halkına sunulacak hizmetlerin istenilen özelliklere sahip olmasıdır (Harman, 2010).

Denizli Belediyesinin misyonu "Önce insan anlayışıly hizmette adalet ve eşitliği ilke edinerek tarihi ve çevresel değerlerine sahip çıkan, sağlık ve refah içinde yaşanabilir bir kent oluşturmak"tır. Vizyonu ise “Gelişimde öncü, insana ve çevreye duyarlı, marka bir şehir olmak”tır. Bu vizyon ve misyonu doğrultusunda gerçekleştirdiği bazı sosyal sorumluluk projeleri aşağıdaki gibidir (www.denizli.bel.tr);

\section{Bilgi Evleri}

Bilgi Evi ve Kurs Merkezi Denizli Büyükşehir Belediyesi tarafından, ilk ve ortaokul çağındaki çocukların geleceğe daha iyi hazırlanmaları amacıyla açılmıştır. Denizli Büyükşehir Belediyesi'nin kentin 10 ayrı noktasında hizmet verdiği Bilgi Evi ve Kurs Merkezlerine birçok öğrenciye hizmet vermektedir. Projenin amacı, öğrencilerin, bilgiye ulaşmasını kolaylaştırmak, boş zamanlarını faydalı etkinliklerle değerlendirmelerini sağlamak, ev ödevlerinin yapılmasında rehberlik etmek ve bilimsel ve sosyal anlamda geleceğe hazırlanmalarına yardımcı olmaktır.

\section{El Emeği Pazart}

2010 yılında kurulan, her türlü sorunuyla Kadın Meclisi'nin ilgilendiği ve her hafta Cumartesi günleri Pelitlibağ Pazarında kurulan El Emeği Pazarı, yedi yıldır düzenli bir biçimde çalışmalarına devam etmektedir. 
Aynı zamanda hafta içi de çeşitli Pazar yerlerinde stant açarak ev ekonomilerine katkı sağlayan kadınlarımızın sayısı her geçen gün artmaktadır. Şuan 70 kadınımız bulunmaktadır.

\section{Kurslar}

KİHEP (Kadının İnsan Hakları Eğitim Programı) eğitmenliğini Sosyal Hizmetler Uzmanı Ayşegül Aksu'nun yaptığı eğitimler 3 ay boyunca sürmüştür. Milli Eğitim Müdürlüğü ile ortak olarak düzenlenen 'Çocuk Bakım Kursu', Naz Bağcı tarafından 6 ay boyunca verilmiştir. Halk Eğitim'in desteğiyle yapılan 'El Sanatları Kursu'nun eğitmenliğini Ayten Bağcı üstlenmiş ve kurs 8 ay boyunca sürmüştür. KOSGEB ile kadın girişimcilik kursu 30 kadın katılımcı ile 4 gün sürmüş, eğitim Kent Konseyi Eğitim Salonunda gerçekleşmiştir. Bu eğitim periyodik olarak 2 ayda bir olmak üzere Kent Konseyinde kadınlar için tekrarlanmaktadır.

\section{Gençlik Meclisi}

Denizli ilinde genç nüfusun ağırlığı dikkat çekicidir. 31 ARALIK 2014 Nüfus Kayıt verilerine göre Denizli'de 15-30 yaş aralığında yaşayan toplam genç nüfus sayısı; 219.389 dır. 2013 yılında il nüfusunun \%36's 25 yaşın altındadır. 25-65 yaş arası nüfus toplam nüfusun \%54'ünü, 65 yaş üstü nüfus toplam nüfusun \%10'unu oluşturmaktadır. 1998 yılında bir grup genç tarafından dönemin belediye başkanı Ali Marım'ın destekleriyle kurulan Denizli Gençlik Meclisi, 1999 yılında dönemin Belediye Başkanı Ali Aygören'in büyük destekleriyle tüzügü belediye meclisi tarafindan onaylanan ilk gençlik meclisi olmuştur

\section{Bilişim Projeleri}

Denizli Gençlik Meclisi kurulduğu günden bu yana özellikle bilişim alanında çok ciddi proje ve eğitimlere imza atmıştır. Denizli Büyükşehir Belediyesi Kent Konseyi binası içerisinde yer alan Habitat Bilişim akademisinde verilen eğitimlerle 10 ylllık süreçte yaklaşık 3800 kişiye çok çeşitli branşlarda bilgisayar sertifikası verilmiştir. Aynı zamanda 2018 yılı içerisinde gençler için Grafik Tasarım ve Photoshop eğitimi düzenlenmekte ve bu eğitimden gençlerimiz yararlanmaktadır.

\section{Sesi Görenler Sesli Dergisi}

Görme Engelliler Spor Kulübü Derneği ve Denizli Büyükşehir Belediyesi Kent Konseyi Engelliler Meclisi işbirliğinde her ay; Görme Engelli bireylerin sosyal hayata entegrasyonunda evden çıkma konusunda sıkıntı yaşayan bireyleri de dikkate alarak katkı sağlamak ve güncel görme engelliliğine dair, sportif ve sosyal diğer konularda katkı sağlamak, Kent Konseyleri adına bu konudaki sivil çalışmaları desteklemek, Görme engelli bireylerin de hayatın içinde olduğunu hatırlatma adına doğrudan evlerine ulaşmak amacıyla Sesi Görenler Sesli Dergisi hazırlanmaktadır. Böylelikle Denizli Büyükşehir Belediyesi’nin başta olmak üzere tüm yerelin haberleri görme engelli vatandaşlarımıza sesli olarak iletilmektedir.

\section{Çocuk Meclisi}

Çocuk Meclisi, 2008 yılında kurulmuştur. Çocuk Meclisi; çocukların kent yönetimindeki rolünün güçlendirilmesi, sürdürülebilir kalkınma konularında eğitilmesi; bu konuda fikir oluşturmaları ve kent yönetimine aktif katılımda bulunmaları için çalışmaların gerçekleştirildiği bir platformdur. Çocuk Meclisi; çocukların demokratik platformlarda hoşgörü, saygı ve uzlaşmacı bir çerçevede fikir üretmeleri ve kendi eylem planlarını oluşturarak sosyal hayattaki rollerini güçlendirmelerini amaçlamaktadır.

\section{Benim Mahallem Projesi}

Mahalle Meclisleri Projesiyle mahalle ölçeğinde yönetim biri oluşturarak, karar süreçlerine aktif katılımın sağlanması ve kamusal alanın demokratik inşası amaçlanmaktadır. Mahalle Meclisleri Projesi ile mahalle ölçeğinde yönetim birimi oluşturarak, karar süreçlerine halkın katılımının sağlanması ve kamusal alanın inşası amaçlanmaktadır. $\mathrm{Bu}$ amaç ile hareket ederek bu güne kadar 22 mahalle de Mahalle Meclisleri kuruldu. Mahalle meclisi kurduğumuz mahaller; Zeytinköy, Hacıkaplanlar, Muratdede, Bahçelievler, Anafartalar, İlbade, Fatih, akçeşme, Gültepe, Yunus Emre, Sevindik, Karahasanlı, Pelitlibağ, Değirmenönü Aktepe, Karşıyaka, Başkarcı, Korucuk, Hürriyet, Cumhuriyet, Kayıhan Mahallesidir.

\section{Sağllklı Evlilik Okulu}

24 Ocak 2012 tarihinde Denizli Belediyesi’nin Ailemi Seviyorum Projesi kapsamında hayata geçirdiği Sağlıklı Evlilik Okulu haftada 2 gün toplam 16 saattir. Sağlıklı Evlilik Okulu açıldığg günden bu güne toplam 34 Grup eğitim almıştır, 34 Grubun sonunda 1315 mezun vermiştir. Denizli' de aile birliğinin korunmas1 ve mutlu evlilikler oluşturulması için harekete geçirdiği Belediyemizin Türkiye'ye örnek olacak Sağlıkı Evlilik Okulu projesidir.

\section{Denizli Belediyesi Down Kafe Projesi}

Denizli Büyükşehir Belediyesi tarafından 2015'de hayata geçirilen proje kapsamında down sendromlu gençlerin çalıştığı Down Kafeterya hizmete açılmıştır. Türkiye'ye örnek olan projede özel çocukların toplumsal yaşantıya katılımlarını sağlamak hedeflenirken, proje büyük yankı uyandırmıştır. 


\section{ARAŞTIRMANIN YÖNTEMI}

\subsection{Araştırmanın Amacı, Önemi, Kapsamı}

Sosyal sorumluluk projeleri belediyelerce toplumun tamamına fayda yaratmak adına oluşturulan projelerdir. Araştırma belediyeler tarafından yapılan projeler kapsamaktadır. $\mathrm{Bu}$ araştırmanın amacı belediyeler tarafından halka sunulan sosyal sorumluluk projelerine yönelik halkın bakış açısını Denizli Belediyesi örnekleminde ortaya koymaktır.

\subsection{Araştırmanın Evreni}

Araştırma belediyelerin sunmuş olduğu sosyal sorumluluk projelerine halkın bakış açısını ortaya koymak amaciyla oluşturulmuştur. Araştırmanın evreni Türkiye genelindeki tüm il ve ilçe belediye projelerinden faydalanan halkı kapsamaktadır. Araştırma evrenine ulaşmanın çok fazla zaman ve maliyet oluşturması nedeniyle örneklem olarak büyük şehir belediyesi olarak halka hizmet veren Denizli büyükşehir belediyesinin projelerinden faydalanan Denizli halkı seçilmiştir. Araştırmada Yazıcıoğlu ve Erdoğan (2004)'ın bilinmeyen durumlarda $\% 5$ hata payı ile örneklem hesaplama tablosu referans alınmıştır. Örneklemin tam olarak bilinmemesi nedeniyle \%5 hata oranında 100.000-100.000.000 vatandaş aralığında örneklemin miktarı 384 katılımcı olarak belirlenmiştir. Bu sebeple örneklem Denizli'de ikamet eden, avm, çarşı vs yerlerde tesadüfi yöntemle seçilmiş vatandaşlardan oluşmuştur. 500 anket dağıtılmış tam ve doğru doldurulmuş 350 vatandaştan geçerli geri dönüş elde edilmiştir.

\subsection{Veri Toplama Yöntemi ve Hipotezler}

Araştırmada anket yönteminden yararlanılmıştır. Anketler yüz yüze görüşerek uygulanmış ve iki bölümden oluşmaktadır. İlk bölümde demografik bilgiler, ikinci bölümde belediyelerin sosyal sorumluluk projelerine halkın bakış açısını ortaya koymaya yönelik ifadeler yer almaktadır.

Belediyelerin Sosyal Sorumluluk Projelerine halkın bakış açısını ölçmek amacıyla kullanılan ölçek, Akman (2009) tarafından yüksek lisans tezinde uyarlanıp güvenirlik ve geçerliliği (Cronbach Alpha :0.89) bulunan ölçektir. Ölçek 7 boyuttan oluşmaktadır. Belediyelerin Sosyal Sorumluluk Projelerine halkın bakış açısını ölçmek amacıyla kullanılan ölçeğin boyutları aşağıdaki gibidir:

1.Sosyal Refaha İlişkin Sosyal Sorumluluk, 2. Kent Ve Çevreye Karsı Sorumluluk 3. Eğitim Ve Kültürel Sorumluluk 4. Çalışanlara Karsı Sorumluluk 5. Siyasal Ve Politik Sorumluluk 6. Sağlıkla İlgili Sorumluluk 7. İnsan Hak Ve Özgürlükleri İle İlgili Sorumluluk.

Sosyal Refaha ilişkin sosyal sorumluluk boyutunda katılımcılara, "Belediye sosyal refahı arttırıcı her türlü faaliyeti destekler", "Ulaşım hizmetlerini yerine getirir ve sorunları gidermek için yeni çözümler arar" gibi sorular sorulmuştur. Kent ve Çevreye karşı sorumluluk boyutu kapsamında katılımcılara, "Belediye, çevrenin korunması (ağaçlandırma, peyzaj) konusunda gerekli duyarlılıkları gösterir", "İmar çalışmaları ve kaçak yapılaşma ile ilgili faaliyetleri ile kentsel dönüşüme katkı sağlar" gibi sorular sorulmuştur. Eğitim ve Kültürel sorumluluk boyutu kapsamında katılımcılara, "Belediye, halk1 sorumluluk konusunda bilinçlendirmeye yönelik eğitici faaliyetlerde bulunur", "Toplumdaki fertlerin sosyal yasamın bir gereği olan kültürel aktiviteleri yapabilmesine olanak sağlar" gibi sorular sorulmuştur. Çalışanlara Karşı sorumluluk boyutu kapsamında katılımcılara, "Çalışanları motive edebilmek için maddî, manevî her tür ihtiyaçlarını karsılar", "Personelinin gelişmesi için fırsat yaratır. (Hizmet içi, Eğitim, Seminer vb.)" gibi sorular sorulmuştur. Siyasal ve politik sorumluluk kapsamında katılımcılara, "Vatandasın siyasi ve ideolojik tercihlerine karsı saygılıdır", "Vatandaşa hizmet sunarken, siyasi ve ideolojik bakımdan ayrım yapmaz" gibi sorular sorulmuştur. Sağlıkla ilgili sorumluluk kapsamında katılımcılara, "Sağlığın korunması ve geliştirilmesi için gerekli sorumluluklarını yerine getirir", "Sağlık otobüsleri oluşturarak yaygın hastalıklarla ilgili vatandaşları bilinçlendirir ( Kalp, kolesterol, tansiyon, ası, grip vb.)" gibi sorular sorulmuştur. İnsan hak ve özgürlükleri ile ilgili sorumluluk kapsamında katılımcılara, "Kişinin yasama hakkına, maddî ve manevî varlığının bütünlügüne yönelik her türlü tedbiri alır", "Belediye, yaptığı her türlü faaliyette insan haklarını ve özgürlüklerini temel alır" gibi sorular yöneltilmiştir. Ölçek maddeleri " $\mathbf{1}=$ Kesinlikle katılmıorum ve $\mathbf{5}=$ Kesinlikle katılıyorum" biçimindeki beşli Likert Ölçeği yardımıyla değerlendirilmiştir.

$\mathrm{Bu}$ doğrultuda araştırmanın hipotezleri aşağıdaki gibidir;

H1 1 : Araştırmaya katılanların sosyal sorumluluk projelerine yönelik bakış açıları cinsiyete göre farklılık göstermektedir.

H2 : Araştırmaya katılanların sosyal sorumluluk projelerine yönelik bakış açıları yaşa göre farklılık göstermektedir. 
$\mathbf{H 3}_{1}$ : Araştırmaya katılanların sosyal sorumluluk projelerine yönelik bakış açıları eğitim seviyesine göre farkl11ık göstermektedir.

H4 $4_{1}$ Sosyal sorumluluk boyut ortalamaları arasında fark vardır.

\subsection{Güvenilirlik Analizi}

Araştırmada kullanılan ölçek 7 boyut ve 37 sorudan oluşmaktadır. Bu doğrultuda katılımcıların verdiği cevaplar doğrultusunda verilerin güvenilirlikleri hesaplanmıştır. SPSS programı ile yapılan güvenilirlik analiz sonucu 37 sorudan oluşan anketin güvenilirliği (Cronbach Alpha) \% 88,3 bulunarak, kullanılan ölçeğin yüksek oranda güvenilir olduğu sonucuna ulaşılmıştır.

\subsection{Araştırmanın Bulguları}

\subsubsection{Demografik Bulgular}

Anketin birinci bölümünde yer alan demografik sorulara katılımcıların yanıtlarına göre frekans analizi uygulanmıştır. Analiz sonuçlarına göre katılımcıların \%51,7‘si kadın, \% 51,4’ü evli, \%31,4’ü 26-35 yaş aralığında, \%29,7'si lisans mezunudur.

Tablo 2.1. Demografik Bulgular

\begin{tabular}{|c|c|c|c|}
\hline \multirow{4}{*}{ Cinsiyet } & & Frekans & Oran \\
\cline { 2 - 4 } & Kadın & 181 & 51,7 \\
\cline { 2 - 4 } & Erkek & 169 & 48,3 \\
\hline \multirow{3}{*}{ Medeni Durum } & Evli & 180 & 51,4 \\
\cline { 2 - 4 } & Bekâr & 170 & 48,6 \\
\cline { 2 - 4 } & $18-25$ arası & 71 & 21,1 \\
\cline { 2 - 4 } & $26-35$ aras1 & 110 & 31,4 \\
\cline { 2 - 4 } & $36-45$ aras1 & 85 & 24,3 \\
\cline { 2 - 4 } & $46-65$ aras1 & 64 & 18,3 \\
\hline \multirow{4}{*}{ Yaş } & 66 ve üzeri & 17 & 11,4 \\
\cline { 2 - 4 } & İlköğretim & 40 & 12,9 \\
\cline { 2 - 4 } & Ortaöğretim & 45 & 26,6 \\
\cline { 2 - 4 } & Lise & 93 & 19,4 \\
\cline { 2 - 4 } & Ön lisans & 68 & 29,7 \\
\cline { 2 - 4 } & Lisans & 104 & 100 \\
\hline
\end{tabular}

\subsubsection{Farklılık Testleri}

Birbirinden bağımsız 2 grubun veya örneklemin bağımlı bir değişkene göre ortalamalarının karşılaştırılarak ortalamalar arasındaki farkın belirli bir güven düzeyinde (\%95, \%99 gibi ) anlamlı olup olmadığını test etmek için kullanılan istatistiksel bir tekniktir (Ural , 2006,200).

\subsubsection{Cinsiyete Göre Bağımsız Örneklem t Testi}

Araştırmada kadınların ve erkeklerin sosyal sorumluluk projelerine bakış açılarını incelemek için ölçek boyutlarına "bağımsız örneklemler için $\boldsymbol{t}$ testi" yapılmıştır. Tüm boyutlar için $\mathrm{p}$ değerleri 0,05 'den büyük çıktığı için istatistiksel bakımdan anlamlı bir farklılığın olmadığı anlaşılmıştır. Yani Denizli belediyesinin sunmuş olduğu sosyal sorumluluk projelerine, kadın ve erkek vatandaşların bakış açılarında herhangi bir farklılığa rastlanmamıştır. H1 1 hipotezi reddedilir. 
Tablo 2.2. Cinsiyete Göre Bağımsız Örneklem t Testi

\begin{tabular}{|l|l|r|r|r|r|r|r|}
\hline \multicolumn{2}{|c|}{ Cinsiyet } & N & Mean & $\begin{array}{c}\text { Std. } \\
\text { Deviation }\end{array}$ & $\begin{array}{c}\text { Std. Error } \\
\text { Mean }\end{array}$ & t & $\mathrm{p}$ \\
\hline \multirow{2}{*}{ Refah } & Kadın & 181 & 4,0110 &, 57349 &, 04263 &,- 568 &, 570 \\
\cline { 2 - 8 } & Erkek & 169 & 4,0444 &, 51962 &, 03997 &,- 570 &, 569 \\
\hline \multirow{2}{*}{ Kent } & Kadın & 181 & 3,8336 &, 61849 &, 04597 &,- 042 &, 966 \\
\cline { 2 - 8 } & Erkek & 169 & 3,8361 &, 46962 &, 03612 &,- 043 &, 966 \\
\hline \multirow{2}{*}{ Eğitim } & Kadın & 181 & 3,7514 &, 61379 &, 04562 &,- 265 &, 791 \\
\cline { 2 - 8 } & Erkek & 169 & 3,7692 &, 64807 &, 04985 &,- 264 &, 792 \\
\hline \multirow{2}{*}{ Çalışan } & Kadın & 181 & 3,8453 &, 53825 &, 04001 & 1,566 &, 118 \\
\cline { 2 - 8 } & Erkek & 169 & 3,7538 &, 55420 &, 04263 & 1,564 &, 119 \\
\hline \multirow{2}{*}{ Siyasal } & Kadın & 181 & 3,4346 &, 97065 &, 07215 & 1,416 &, 116 \\
\cline { 2 - 8 } & Erkek & 169 & 3,1815 &, 98933 &, 07610 & 1,414 &, 116 \\
\hline \multirow{2}{*}{ Sağlık } & Kadın & 181 & 4,1459 &, 46565 &, 03461 &, 944 &, 346 \\
\cline { 2 - 8 } & Erkek & 169 & 4,0994 &, 45362 &, 03489 &, 945 &, 345 \\
\hline \multirow{2}{*}{ İnsan } & Kadın & 181 & 3,7500 &, 63792 &, 04742 &, 921 &, 358 \\
\cline { 2 - 8 } & Erkek & 169 & 3,6879 &, 62248 &, 04788 &, 922 &, 357 \\
\hline
\end{tabular}

\subsubsection{Yaşa Göre ANOVA Testi}

Araştırmada katılımcıların yaş gruplarına göre sosyal sorumluluk projelerine bakış açılarını incelemek için “ANOVA testi” yapılmıştır. Tüm boyutlar için p değerleri 0,05 'den büyük çıktığı için istatistiksel bakımdan anlamlı bir farklılığın olmadığı anlaşılmıştır. Yani Denizli belediyesinin sunmuş olduğu sosyal sorumluluk projelerine, tüm yaş grubundaki vatandaşların bakış açıları arasında herhangi bir farklılığa rastlanmamıştır. H21 hipotezi reddedilir.

Tablo 2.2. Yaşa Göre ANOVA Testi

\begin{tabular}{|c|c|c|c|c|c|c|}
\hline & & Sum of Squares & Df & Mean Square & $\mathrm{F}$ & Sig. \\
\hline \multirow[t]{3}{*}{ Refah } & Gruplar Aras1 & 1,225 & 4 & ,406 & 1,942 & ,109 \\
\hline & Gruplar İçinde & 101,434 & 345 & 294 & & \\
\hline & Toplam & 104,659 & 349 & & & \\
\hline \multirow[t]{3}{*}{ Kent } & Gruplar Aras1 &, 584 & 4 & ,146 & ,479 &, 751 \\
\hline & Gruplar İicinde & 105,323 & 345 & ,305 & & \\
\hline & Toplam & 105,907 & 349 & & & \\
\hline \multirow[t]{3}{*}{ Eğitim } & Gruplar Aras1 & 1,255 & 4 & ,314 & ,789 & ,533 \\
\hline & Gruplar İicinde & 137,145 & 345 & ,398 & & \\
\hline & Toplam & 138,400 & 349 & & & \\
\hline \multirow[t]{3}{*}{ Çalışan } & Gruplar Aras1 & ,604 & 4 & ,151 & ,502 & ,735 \\
\hline & Gruplar İçinde & 103,875 & 345 & ,301 & & \\
\hline & Toplam & 104,480 & 349 & & & \\
\hline \multirow[t]{3}{*}{ Siyasal } & Gruplar Arası & 5,327 & 4 & 1,332 & 1,374 & ,242 \\
\hline & Gruplar İçinde & 334,297 & 345 & ,969 & & \\
\hline & Toplam & 339,624 & 349 & & & \\
\hline \multirow[t]{3}{*}{ Sağlık } & Gruplar Aras1 & 1,602 & 4 & ,400 & 1,914 & , 108 \\
\hline & Gruplar İंcinde & 72,186 & 345 & 209 & & \\
\hline & Toplam & 73,788 & 349 & & & \\
\hline \multirow[t]{3}{*}{ İnsan } & Gruplar Arası & 1,183 & 4 & ,296 & ,742 & ,564 \\
\hline & Gruplar İçinde & 137,502 & 345 & ,399 & & \\
\hline & Toplam & 138,685 & 349 & & & \\
\hline
\end{tabular}




\subsubsection{Eğitim Durumuna Göre ANOVA Testi}

Araştırmada katılımcıların eğitim seviyelerine göre sosyal sorumluluk projelerine bakış açılarını incelemek için "ANOVA testi” yapılmıştır. Tüm boyutlar için p değerleri 0,05 'den küçük çıktığı için istatistiksel açıdan anlamlı bir farklılığın olduğu anlaşılmıştır. Yani Denizli belediyesinin sunmuş olduğu sosyal sorumluluk projelerine, farklı eğitim grubundaki vatandaşların bakış açıları arasında farklılığa rastlanmıştır. H3 1 hipotezi kabul edilir.

Tablo 2.3. Eğitim Durumuna Göre ANOVA Testi

\begin{tabular}{|c|c|c|c|c|c|c|}
\hline & & Sum of Squares & df & Mean Square & $\mathrm{F}$ & Sig. \\
\hline \multirow[t]{3}{*}{ Refah } & Gruplar Arası & 3,308 & 4 & ,827 & 2,815 & ,025 \\
\hline & Gruplar İçinde & 101,351 & 345 & 294 & & \\
\hline & Toplam & 104,659 & 349 & & & \\
\hline \multirow[t]{3}{*}{ Kent } & Gruplar Arası & 2,710 & 4 & ,427 & 2,415 & ,028 \\
\hline & Gruplar İçinde & 104,198 & 345 &, 302 & & \\
\hline & Toplam & 105,907 & 349 & & & \\
\hline \multirow[t]{3}{*}{ Eğitim } & Gruplar Aras1 & 4,747 & 4 & 1,187 & 3,063 & ,017 \\
\hline & Gruplar İçinde & 133,653 & 345 & ,387 & & \\
\hline & Toplam & 138,400 & 349 & & & \\
\hline \multirow[t]{3}{*}{ Çalışan } & Gruplar Arası & 3,392 & 4 & ,848 & 2,894 & ,022 \\
\hline & Gruplar İçinde & 101,088 & 345 & ,293 & & \\
\hline & Toplam & 104,480 & 349 & & & \\
\hline \multirow[t]{3}{*}{ Siyasal } & Gruplar Arası & 15,510 & 4 & 3,877 & 4,127 & ,003 \\
\hline & Gruplar İçinde & 324,115 & 345 & ,939 & & \\
\hline & Toplam & 339,624 & 349 & & & \\
\hline \multirow[t]{3}{*}{ Sağlık } & Gruplar Arası & 3,404 & 4 & ,851 & 4,171 & ,003 \\
\hline & Gruplar İçinde & 70,384 & 345 & ,204 & & \\
\hline & Toplam & 73,788 & 349 & & & \\
\hline \multirow[t]{3}{*}{ İnsan } & Gruplar Arası & 4,273 & 4 & 1,068 & 2,742 & ,029 \\
\hline & Gruplar İçinde & 134,412 & 345 & ,390 & & \\
\hline & Toplam & 138,685 & 349 & & & \\
\hline
\end{tabular}

\subsubsection{Boyutlara Göre Farklılık Testleri}

Tablo 2.4'e bakıldığında vatandaşların genel olarak sosyal sorumluluk projelerini algılama ortalamalarının $(X=3,7970 ; s s=0,6217)$ 3'ün üstünde çıktığı görülmektedir. Bu değerlere göre araştırmaya katılanların belediyenin faaliyetleri ilgili algılarının genel olarak olumlu olduğu anlaşılmaktadır. Tablodaki değerlere göre araştırmaya katılanların en düşük kabul ettikleri sosyal sorumluluk boyutu "Siyasal Ve Politik Sorumluluk" $(\mathrm{x}=3,3124 ; \mathrm{ss}=, 9865)$ iken "Sağlikla İlgili Sorumluluk" $(\mathrm{x}=4,1234 ; \mathrm{ss}=, 4598)$ kabul görülen en yüksek sosyal sorumluluk boyutudur. Bu değerlere göre araştırmamızın ikinci hipotezi olan sosyal sorumluluk boyutları ortalamaları arasında fark vardır seklindeki $\mathrm{H}_{1}$ hipotezi kabul edilmektedir.

Tablo 2.4. Boyutlara Göre Farklılık Testleri

\begin{tabular}{|l|l|l|}
\hline & Ortalama & Standart Hata \\
\hline 1. Sosyal Refaha İlişkin Sosyal Sorumluluk & & \\
\hline 2. Kent Ve Çevreye Karsı Sorumluluk & 4,0271 &, 54761 \\
\hline 3. Eğitim Ve Kültürel Sorumluluk & 3,8348 &, 55087 \\
\hline 4. Çalışanlara Karsı Sorumluluk & 3,7600 &, 62973 \\
\hline 5. Siyasal Ve Politik Sorumluluk & 3,8011 &, 54715 \\
\hline 6. Sağlıla İlgili Sorumluluk & 3,3124 &, 98648 \\
\hline 7. İnsan Hak Ve Özgürlükleri İle İlgili Sorumluluk & 4,1234 &, 45981 \\
\hline GENEL ORTALAMA & 3,7200 &, 63038 \\
\hline
\end{tabular}




\section{SONUÇ VE ÖNERILER}

Tüm sosyal sorumluluk boyutlarında sosyal sorumluluk algı ortalamalarının kadın ve erkekler ile farklı yaş gruplarındaki vatandaşlar arasında sosyal sorumluluk projelerine algılama açısından herhangi bir farklılık olmadığı sonucuna ulaşılırken, eğitim seviyesine göre bakış açısında farklılık olduğu sonucuna ulaşılmıştır. Yani farklı eğitim seviyesindeki bireyler, sosyal sorumluluk projelerini farklı yorumlamaktadırlar.

Araştırmaya katılanların belediyenin gerçekleştirdiği ve toplumun kabul gördüğü en düşük sosyal sorumluluk boyutu "Siyasal Ve Politik Sorumluluk" iken "Sağlıkla İlgili Sorumluluk" kabul görülen en yüksek sosyal sorumluluk boyutudur.

Denizli ili örnekleminde araştırma sonuçlarını göz önüne alarak, yerel yönetimlerin sosyal sorumluluk düzeylerinin çeşitli faktörler arasında değişkenlik gösterdiğini görmekteyiz. Analiz sonuçlarında düşük çıkan değerlerin yükselmesi adına yerel yönetimlerin çabalarını ve sorumluluk bilinçlerini halkın yerel isteklerini anket kamuoyu araştırmalarına daha çok ağırlık vererek en muazzam sonuca ulaşılabileceği önerilebilir. 


\section{KAYNAKÇA}

Akman, Elvettin (2009). "Yerel Yönetimlerde Sosyal Sorumluluk Yönetimi: Çankaya Belediyesi Örneği”, Yüksek Lisans Tezi, Sakarya Üniversitesi, Sosyal Bilimler Enstitüsü, Sakarya.

Bakan, İsmail ve Doğan, İnci Fatma, (2011). Kurumsal Sosyal Sorumluluk, (içinde) Yönetimde Çağdaş ve Güncel Konular, Kavramlar, İlkeler, Uygulamalar ve Yaklaşımlar, Editör: İsmail Bakan, Gazi

Kitapevi, Ankara.

Çelik, Adnan (2007), "Şirketlerin Sosyal Sorumlulukları", (içinde) Kurumsal Sosyal Sorumluluk, ed.Coşkun Can Aktan, İGIAD Yayın1, İstanbul, s.61-82.

Efil, İsmail, (2013). İşletmelerde Yönetim ve Organizasyon, Dora Basım, Yayım, Dağıtım, Bursa.

Gülcan, Nazlıgül, (2019). İşletmelerin Sosyal Sorumluluk Faaliyetlerinin Finansal Performanslarına Etkisi,

Doktora Tezi, Burdur Mehmet Akif Ersoy Üniversitesi, Sosyal Bilimler Enstitüsü, Burdur.

Harman, Ata (2014). Yerel Anlamda Kurumsal Sosyal Sorumluluk Projelerinin Sosyal Fayda Boyutu:

Kocaeli Örneği”, Yüksek Lisans Tezi, Sakarya Üniversitesi, Sosyal Bilimler Enstitüsü, Sakarya.

Sarıca, Y.Pınar Soykut ve Yüksel, Elçin (2012). Yerel Yönetimlerde Sosyal Sorumluluk Projesi Uygulaması

Olarak Sosyal Hayata Katılım: Engelsiz Yaşam, Çalışma İlişkileri Dergisi, 3(1), 48-66.

Şimşek, M. Şerif, Çelik, Adnan, Akgemci Tahir, (2016). Davranış Bilimlerine Giriş ve Örgütlerde Davranış, Eğitim Yayınevi, Konya.

Şimşek, M. Şerif, Çelik, Adnan, (2015). İşletme Bilimine Giriş, Eğitim Yayınevi, Konya.

Tekin, Erol, (2018). Kurumsal Sosyal Sorumluluk Faaliyetlerinde Sosyal Medyanın Rolü: GSM Firmaları

Örneği, Kastamonu Üniversitesi İktisadi ve İdari Bilimler Fakültesi Dergisi 20(1), 31-55.

Yazıcıŏ̆lu, Yahşi ve Erdoğan Samiye (2014). SPSS Uygulamalı Bilimsel Araştırma Yöntemleri. (4. Baskı)

Ankara: Detay Yayınları.

Ural A. , Kılıç İ., (2006). Bilimsel Araştırma Süreci ve SPSS ile Veri Analizi.(2.Baskı).Ankara : Detay

Anatolia Akademik Yayıncılık Ltd. Şti.

- www.denizli.bel.tr 